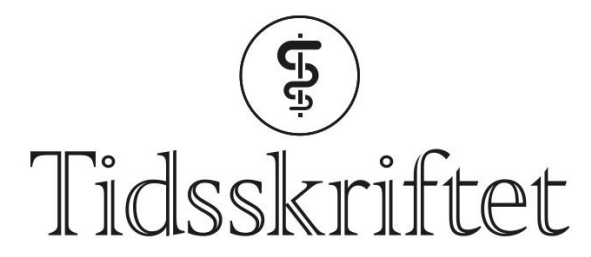

DEN NORSKE LEGEFORENING

\title{
Influensavaksine er trygt i svangerskapet
}

FRA ANDRE TIDSSKRIFTER

SOFIE PAUS

Tidsskriftet

Vaksinering mot pandemisk influensa $\mathrm{A}\left(\mathrm{H}_{1} \mathrm{~N}_{1}\right)$ under svangerskapet ga ingen uheldige følger hos barna i en stor kohortstudie.

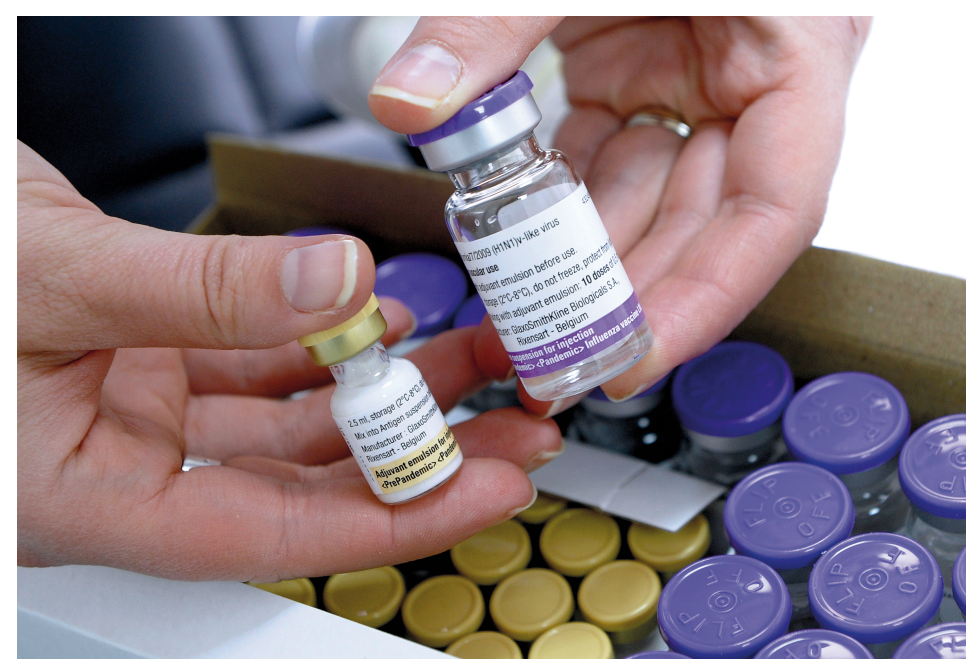

Illustrasjonsfoto: Reuters / NTB scanpix

I en retrospektiv kohortstudie med rundt 104 ooo levendefødte barn født i perioden 2009-10 var rundt en tredel født av mødre som ble vaksinert mot pandemisk influensa $\mathrm{A}\left(\mathrm{H}_{1} \mathrm{~N} 1\right)$ under svangerskapet (1). Ved koplinger mellom ulike databaser ble sammenhengen mellom eksponering for vaksine og utvikling av immunrelaterte sykdommer (bl.a. infeksjoner og astma), ikke-immunrelaterte sykdommer (bl.a. kreft og kognitiv svikt) og dødelighet studert. Studien viste ingen sikre sammenhenger. Det var en svak assosiasjon mellom influensavaksine og astma, og en svak invers assosiasjon med gastrointestinale infeksjoner.

- Denne studien er viktig for å styrke sikkerheten og minke skepsisen til influensavaksiner til gravide, sier Siri Eldevik Håberg, som er fagdirektør ved Folkehelseinstituttet.

- Svake sammenhenger kan delvis forklares med konfundering, dvs. at kvinner som er vaksinert, kan tenkes å søke helsehjelp oftere. Det er betryggende at man ikke fant økt risiko for kreft, infeksjoner, kroniske sykdommer, sykehusinnleggelser eller død hos de eksponerte barna. Antistoffer fra mor overføres til barnet under svangerskapet, noe som vil 
beskytte det nyfødte barnet mot influensa de første levemånedene. Dette er viktig, fordi nyfødte har et umodent immunsystem og er for små til å vaksineres, samtidig som de har $\emptyset \mathrm{kt}$ risiko for alvorlig influensasykdom, påpeker Håberg, som understreker at helsepersonell må informere godt om risiko ved influensa i svangerskapet og tilby influensavaksine til gravide.

LITTERATUR:

1. Walsh LK, Donelle J, Dodds L et al. Health outcomes of young children born to mothers who received 2009 pandemic H1N1 influenza vaccination during pregnancy: retrospective cohort study. BMJ 2019; 366: 14151. [PubMed][CrossRef]

Publisert: 12. februar 2020. Tidsskr Nor Legeforen. DOI: 10.4045/tidsskr.20.0071

C Tidsskrift for Den norske legeforening 2020. Lastet ned fra tidsskriftet.no 